・综述・

\title{
中国西北干旱区和中亚植物区系地理研究
}

\author{
张明理 $1,2 *$ \\ 1 (中国科学院植物研究所, 北京 100093) \\ 2 (中国科学院干旱区生物地理与生物资源重点实验室, 中国科学院新疆生态与地理研究所, 乌鲁木齐 830011)
}

\begin{abstract}
摘要: 本文简要回顾了我国西北干旱区植物区系地理的研究历史, 其中植物区系和科属地理两方面的研究大多集 中在1980年代以后。西北干旱区作为中亚干旱区的东部, 今后应该拓展到西部的前苏联中亚五国, 在一个自然地 理区域的基础上开展区系地理研究才有更广泛的意义。分子系统发育和生物地理研究对区系地理研究有重要意义 和潜力。对区系和植被中的关键类群, 只有进行深入的分子生物地理学研究, 才能使区系地理研究向纵深发展。 类群的研究, 也应该联系青藏高原隆升和古地中海西退等历史和地质事件, 因为它们是中亚干旱的非生物的历史 成因。
\end{abstract}

关键词: 西北干旱区; 中亚; 区系; 分子系统发育

\section{A review on the floristic phytogeography in arid northwestern China and Central Asia}

Mingli Zhang ${ }^{1,2^{*}}$

1 Institute of Botany, Chinese Academy of Sciences, Beijing 100093

2 Key Laboratory of Biogeography and Bioresource in Arid Land, Xinjiang Institute of Ecology and Geography, Chinese Academy of Sciences, Urumqi 830011

\begin{abstract}
A floristic phytogeography of arid regions of northwestern China is outlined in this paper. Most researches of floristic cataloging and phytogeography of families and genera were started since 1980. We propose that Central Asia, as a natural region, should be regarded as a distinct unit to study, namely combining northwestern China, Kazakhstan, Uzbekistan, Kyrgyzstan, Tajikistan and Turkmenistan as one unit. Local research is not sufficient or holistic for study of plant floristics and evolutionary history. We address the significance and potential of molecular phylogeny and biogeography of families and genera. Linking geological and palaeoclimate events, especially the Qinghai-Tibetan Plateau uplift and the Tethys retreat in the historical floristic phytogeography and vegetation, is suggested as they are the main dynamics of Central Asian aridification.
\end{abstract}

Key words: arid northwestern China; Central Asia; floristics; molecular phylogeny

西北干旱区、东部季风区和青藏高寒区并称我 国三大自然地理区(中国科学院《中国自然地理》编 辑委员会, 1985)。西北干旱区地处亚洲内陆, 自晚 新生代以来逐渐形成了干旱和半干旱气候, 其自东 向西, 以鄂尔多斯-贺兰山为界, 分为两个自然地 区：内蒙古草原(半干旱气候)和西北荒漠(干旱气 候)(中国科学院《中国自然地理》编辑委员会, 1985)。前苏联植物学家多将我国西北干旱区称为
“亚洲中部”(Central Asia), 而将前苏联中亚五国(哈 萨克斯坦、乌兹别克斯坦、吉尔吉斯斯坦、塔吉克 斯坦、土库曼斯坦)称为“中亚”(Middle Asia)(Grubov, 1999)。吴征镒(1979)认为前者为中亚东部，后者为 中亚西部。而Takhtajan (1986)认为准格尔-图兰(包 括咸里海-图兰低地)为一个整体, 因此, 中亚干旱 区应该包括以我国西北部干旱区为主体(蒙古一喀什 葛尔)的东部区和以前苏联中亚五国为主体(包括准

收稿日期: 2016-12-19; 接受日期: 2017-02-17

基金项目: 国家重点基础研究发展规划项目(2014CB954201)和中国科学院生物多样性保护策略项目(ZSSD-012)

* 通讯作者 Author for correspondence. E-mail: zhangml@ibcas.ac.cn 
格尔, 准格尔-图兰区系)的西部构成的完整自然地 理区域。

虽然干旱区植物区系的种类相对贫乏，但其广 阔的面积、特殊的干旱地理成分和历史成分(雍世鹏 和朱宗元，1990，1992), 使得其在中国植物区系和 欧亚以及北温带植物区系中占有重要地位(王荷生, 1979，1992; 吴征镒和王荷生，1983; Wu \& Wu, 1998; 汤彦承, 2000; 吴征镒等, 2011)。

\section{1 西北干旱区植物区系地理研究历史回顾}

前苏联植物学家对西北干旱区、中亚植物区系 和植被研究作了许多奠基性的工作。著名的如B.I. Grubov (1999)主编的Plants of Central Asia: Plant Collections from China and Mongolia, 这套植物志 主要依据前苏联科学院科马洛夫植物研究所标本 馆的馆藏标本编写完成, 现在已全部翻译成英文。

V.L.Komarov (1908，1945) 基于锦鸡儿属 (Caragana)、白刺属(Nitraria)、淫羊嚄属(Epimedium)、 党参属(Codonopsis)和藤山柳属 (Clematoclethra) 等5 属的研究, 论述了蒙古植物区系的过渡性质和东亚 植物区系的始生性质(Wulff, 1964)。1950年代, 由前 苏联科学院地理研究所A. A. Junatov和中国科学院 植物研究所秦仁昌、关克俭、李安仁、朱家楠、李 世英、胡式之、张佃民、张新时等组成的中国科学 院新疆综合考察队植被与区系考察组, 对新疆植物 进行了系统的考察与采集(中国科学院新疆综合考 察队，1959), 并于1978年出版了《新疆植被及其利 用》一书(中国科学院新疆综合考察队和中国科学院 植物研究所, 1978)。1990年代, 吴征镒院士组织和 主持了国家自然科学基金重大项目“中国种子植物 区系研究”, 其中沈观冕 $(1993)^{(1)}$ 完成了《荒漠植物名 录》, 共记载68科361属1,079种; 杨昌友等(1993) ${ }^{2}$ 完成《中国新疆天山植物名录》, 共记载106科564 属2,175种(变种)。随着各省区植物志的完成, 例如 《新疆植物志》、《内蒙古植物志》、《青海植物志》、 《甘肃植物志》和《宁夏植物志》, 以及《中国沙 漠植物志》、《滩羊区植物志》、《黄土高原植物志》 等等(参见马金双, 2011的详细收集), 干旱区植物物

(1) 沈观冕 (1993) 荒漠植物名录. 中国科学院新疆生物土壤沙漠研究 所, 乌鲁木齐.

(2) 杨昌友, 安争夕, 王兵, 买买提江, 㚞建华, 李烨, 黄俊华 (1993) 中 国新疆天山植物名录. 新疆八一农学院, 乌鲁木齐.
种编目已基本完成。

对一些重要和热点地区的物种编目和区系分 析也有许多积累。如赵一之(2014)对内蒙古区系, 李 学禹等(1998)、赵业涁等(2003)、杨淑萍等(2007)对 中国新疆帕米尔区系的调查和分析，陈文俐和杨昌 友(2000)、曹秋梅等(2015)对中国阿尔泰区系的调查 研究, 朱宗元等(1999)、燕玲等(1999)对阿拉善-鄂 尔多斯物种编目和区系分析，黄俊华等(2014)对萨 吾尔-塔尔巴哈台区系, 徐远杰等(2010)对伊犁-天 山区系，陈鹏和潘晓玲(2001)对河西走廊区系，潘 晓玲(1994)对塔里木区系, 潘晓玲和张宏达(1995) 对柴达木区系, 赵一之(2006)对鄂尔多斯区系, 崔 大方等 $(2000)^{\sqrt{3}}$ 对新疆天山野果林区系, 崔大方等 (2001)对新疆木本植物区系，黄俊华等(2013)对塔 吉克斯坦区系，以及赵一之(1997)对蒙古高原的特 有属、赵一之和朱宗元(2003)对亚洲中部荒漠特有 属，党荣理和潘晓玲(2001)、潘晓玲等(2001)、冯缨 和潘伯荣(2004)对西北干旱荒漠区植物区系的特有 现象的研究。雍世鹏和朱宗元 $(1990,1992)$ 论述了戈 壁荒漠植物的区系、植被。这些研究可以使我们了 解一些重要和热点地区的物种编目, 科、属、种的 组成，以及区系的性质，尤其是某些地区根据采集 鉴定的第一手资料的物种编目, 为植物志提供了详 细的补充，是植物区系分析的基础。

相似性系数是植物区系研究很好的量化指标 (傅德志和左家哺, 1995; 张镱锂, 1998), 应用该系 数, 潘晓玲和左家哺(1997)分析了我国西北干旱区9 个地区植物区系的相似性亲缘, 包括阿尔泰山、准 噶尔盆地、天山、塔里木盆地、阿尔金山、阿拉善、 河西走廊、柴达木盆地和阿里, 结果表明塔里木盆 地、阿拉善、河西走廊和柴达木盆地植物区系关系 密切, 而它们与准噶尔盆地植物区系差异较大; 山 体间(阿尔泰山和天山)的关系不如荒漠区系的关系 密切。任珺和陶玲(2003)依据相似性系数, 将中国20 个沙漠植物区系单元聚类为 3 个大的区系：蒙古沙 漠植物区、西北沙漠植物区和华北沙漠植物区，这 个以区系为基础的分析，与一般植被划分的结果相 一致。

前苏联中亚五国的植物区系和生物多样性编

(3) 崔大方, 廖文波, 孟冬丽, 许正 (2000) 中国天山野果林植物区系组 成及地理成分分析. 全国系统与进化植物学青年学术研讨会会议论文 集, 广州。 
目比我国植物区系的研究要早得多, 其中首先要提 到的是《苏联植物志》(Komarov \& Shishkin (eds.) 1934-1964俄文版，1963-2002英文版), 其中涉及到 中亚五国的区系和地理分布。此后的中亚五国各加 盟共和国的地方植物志, 以及《西伯利亚植物志》, 阿尔泰植物名录, 帕米尔植物名录(详细参阅马金 双, 2011), 以及一些自然保护区的植物名录等, 都 补充和完善了其区系资料。但大量的中亚植物区 系、地理、植被、生物多样性研究多参考《苏联植 物志》, 因为它的确是世界植物区系、植物志中的 巨著和最有价值的参考资料之一。

\section{2 西北干旱区和中亚植物科属地理研究简述}

用一些重点植物科属来论证、推断植物区系的 性质、起源和演化, 历来是植物区系地理研究的重 要内容 (Komarov, 1945; Wulff，1964; 路安民， 1999)。温带荒漠的一些科属, 许多被用来讨论区系 地理的性质。而前苏联区系和中亚科属地理的研究 已积累了一百多年，例如 Iljin (1937)、Bobrov (1965)、Vassilchenko (1982)等的研究。白刺属以中 亚干旱区为生物多样性和分布中心, Komarov $(1908,1947)$ 曾用其作为经典例子, 来阐述冈瓦那板 块的解离和该属的非洲起源并向澳大利亚和中亚 扩散, 从此引发许多学者对此属生物地理研究的关 注, 并提出了许多假设, 如支持Komarov的非洲起 源说(Iljin，1937; Vassilchenko，1982; 潘晓玲等, 1999; Yang, 2006), 中亚本地起源说(Grubov, 1999), 古南大陆起源说 (吴征镒和王荷生, 1983), 古地中海 起源说(潘晓云等, 2003), 以及近年来的中亚东部起 源说(Zhang et al, 2015a)等等。刘媖心(1982)曾用藜

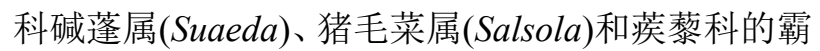
王属(Zygophyllum) 的分布, 讨论了干旱区 5 个分布 区(准噶尔盆地、塔里木盆地、柴达木盆地、河西走 廊和阿拉善)的区系关系, 并进一步论述了荒漠区 系的演化和形成(刘媖心, 1995)。刘慎谔(1985)则用 柽柳属(Tamarix)、甘草属(Glycyhirizia)、霸王属和 白刺属的分布, 讨论了蒙古-新疆沙漠的起源, 表 明我国西北部与中亚共有种是新的关系(地质年代 较近), 而与我国东部共有种是老的关系(地质年代 较远)。朱格麟(1996)讨论了荒漠植物区系中的重要 类群一䔉科的起源演化和分布格局, 赵一之(1993, 2009)对锦鸡儿属的分类分布、张明理(1998)对锦鸡
儿属的地理分布格局，潘晓玲等(1999)对白刺属的 起源演化, 张道远等(2003)对柽柳属起源演化等等 研究，都不同程度地揭示或阐明了科属分布的区系 地理亲缘和关系。需要指出的是, 根据系统发育与 地理分布相一致的原则，一般凡对区系地理亲缘和 分布格局解释得合理和有说服力的类群，都基于其 可靠的、支持率较高的系统发育树; 也就是说，一 个类群合适的生物地理格局和历史研究，都需要一 个可靠的系统发育树。

\section{3 目前植物区系地理研究的几个热点}

\section{1 历史植物地理研究}

近20多年来分子系统学和生物地理学的飞速 发展, 大大推进了植物区系地理的研究, 使人们在 分子层次上认识了生物的进化历史和分布格局。生 物地理学中研究分布格局时采用的分子进化钟模 型(Sanderson，2002; Renner，2005; Drummond \& Rambaut, 2007; Ricklefs, 2007)和祖先分布区推断模 型等(Nylander et al, 2008; Ree \& Smith, 2008; Yu et al, 2015), 为区系地理研究提供了有效的方法, 在 一定程度上能够给出科属类群较确切的起源时间 和起源地点。虽然这些方法应用于干旱区植物类群 的研究并不多, 但也有一些典型的案例, 例如对蒿 属(Artemisia)(Miao et al, 2011)、锦鸡儿属(Zhang et al, 2009, 2015b; Zhang \& Fritsch, 2010)、白刺属 (Temirbayeva \& Zhang, 2015; Zhang et al, 2015a)、木 苶属 (Atraphaxis)(Zhang et al，2014b)、红砂属 (Reaumuria)(Zhang et al, 2014a)、裸果木属 (Gymnocarpos)(Jia et al, 2016)和沙棘 (Hippophä rhamnoides) (Jia et al, 2012)的研究, 都探讨和回答 了类群确切的起源时间和地点, 以及迁移、扩散等 物种形成和演化事件。目前的研究均认为干旱区植 物区系和植被的形成与青藏高原的隆升和古地中 海的西退密切相关(例如 Miao et al, 2012; Zhang et $\mathrm{al}, 2014 \mathrm{a}, \mathrm{b})$, 这应该是合理的解释，因为青藏高原 的隆升和古地中海的西退强烈地引发了干旱气候 的形成和发展, 从而驱动了干旱区植物的进化。如 何更深入地探讨区系、植被和物种进化与地质、气 候历史变迁的关系、作用和机制，需要对大量类群 进行深入研究。

\section{2 植物谱系地理研究}

近10多年来兴起和发展迅速的谱系地理学 
(Phylogeography), 以个别种或若干近缘种的遗传 变异、谱系结构和它们与地质、气候事件的相关性 作为研究手段和目标(Avise, 2000), 研究生物进化 与生态环境的适应, 为区系地理研究补充了许多有 价值的资料和证据, 这些手段和方法也能应用到属 一级水平(例如Liu et al, 2009; Meng \& Zhang, 2013)。国内在青藏高原、东亚已有许多研究(见Qiu et al, 2011), 在干旱区植物地理研究中也有不少积 累, 如沙冬青属(Ammopiptanthus)(Ge et al, 2005)、 四合木(Tetraena mongolica)(Ge et al, 2011)、裸果木 (Gymnocarpos przewalskii)(Ma et al, 2012)、半日花 (Helianthemum songaricum)(Su et al, 2011)、白刺 (Nitraria sphaerocarpa)(Su \& Zhang, 2013)、霸王 (Zygophyllum xanthoxylon)(Shi \& Zhang, 2015)、木苶 (Atraphaxis frutescens)(Xu \& Zhang, 2015)、红砂 (Reaumuria soongarica)( $\mathrm{Li}$ et al, 2012)、船苞翠雀花 (Delphinium naviculare)(Zhang \& Zhang, 2012)、天山 茶蔍子(Ribes meyeri)(Xie \& Zhang, 2013)、林地乌头 (Aconitum nemorum) (Jiang et al, 2014)等, 详见 Meng等(2015)的综述。这些研究都不同程度地分析 了物种(属)的遗传多样性、谱系地理格局、物种分 布的片断化、物种发生分化的时间、扩散方式, 以 及分化的原因等等。

\section{3 数字植物标本馆}

互联网技术的普及和应用使得很多大数据和 巨量数据库, 特别是物种名录、植物标本馆标本数 据库能在网上共享, 例如英国皇家植物园 KEW植 物物种名称索引(http://www.uk.ipni.org/index.html)、 美国密苏里植物园植物系统发育数据库 (http:// www.mobot.org/mobot/research/apweb/), 以及中国 数字植物标本馆 (http://www.cvh.org. cn/), 为物种名 称、编目、分布资料、系统发育关系等信息的查询、 提取和利用提供了方便、快速的工具。今后的区系 地理研究, 借助和应用互联网技术, 可对植物种类 编目、分布等数据进行方便的检索、提取和整合。

\section{4 植物群落谱系学研究}

最近 10 多年发展迅速的群落谱系学 (Community phylogenetics)研究群落中物种的组成 和关系时, 以物种间的系统发育关系为基础, 通过 建立群落中物种的系统发育多样性指数和谱系指 数, 进而评价生态因素(生境过滤和竞争排斥)与进 化过程(物种分化、扩散和灭绝)对群落结构的影响
(Webb et al, 2002; Wiens et al, 2007; Kress et al, 2009; Eiserhardt et al, 2013)。群落系统发育在群落层 次上讨论区系、植被的进化, 显然有别于科属种的 生物进化研究, 在探讨区系地理、生物多样性和环 境因子的解释等方面已显示出潜力(卢孟孟等, 2013, 2014; 米湘成等, 2014; Qian \& Jiang, 2014; Li et al, 2014; 葛学军, 2015)。另外, 植物DNA条形码 用一些标准DNA序列片段识别和鉴定生物物种( $\mathrm{Li}$ et al，2011), 可用于监测和评估当前和过去的生物 多样性(高连明, 2015), 也为植物区系地理研究注入 了活力。

\section{4 未来西北干旱区和中亚区系地理研究的 几点看法}

根据植物生物地理学的发展趋势及西北干旱 区和中亚植物地理研究现状, 这里拟提出我国西北 干旱区和中亚区系地理研究应该注意的几个问题 和研究方向。

\section{1 中亚区系和类群研究的完整性}

要讨论中亚干旱区植物区系地理, 需要区系和 类群两方面基础信息的完整性，也就是说，对有些 植物区系, 我们尚且不知道其自然地理范围内确切 的物种编目，例如天山区系，目前还没有整个天山 的区系资料。在研究时, 不能只涉及中国的天山、 中国的帕米尔、中国的阿尔泰，而应该扩大到整个 天山、整个帕米尔、整个阿尔泰等地区的植物区系。 这就需要我们的研究拓展到中亚五国。当然, 走出 国门进行野外调查采集困难不少，有些几乎是不可 能的，但近年来国家“一带一路”战略的实施，为科 学研究创造了不少条件和机遇, 例如近年来对中亚 五国、喜马拉雅及其邻近地区的考察和采集。

植物区系地理研究也需要科属分类学研究时 类群的完整性。目前的研究还很少有对那些以中亚 干旱区为分布中心的科属作过完整的分类学和区 系地理研究, 多数是对某省、区, 如新疆某科属的 植物分类, 这样的研究不能全面地反映整个中亚干 旱区的区系地理特征，当然也对分布于干旱区植物 类群的分布格局及起源与演化历史研究没有多大 价值。

\section{2 干旱区植物类群的系统发育与起源研究}

如上所述,一个类群可靠的系统发育关系, 是 其分布格局和区系地理研究非常重要的基础。在中 
亚干旱区的类群中, 目前已有的、为数不多的研究 类群，大多基于形态特征演化的系统发育关系。然 而, 我们更需要的是基于分子证据的系统发育与生 物地理研究。研究表明, 只有基于DNA序列数据, 采用分子钟模型、祖先分布区模型等, 才有可能对 植物的起源地点、起源时间作出确切的推断, 进而 推断类群和区系的进化历史。

确定一个类群的起源与演化, 化石资料无疑是 至关重要的。但干旱区目前发掘的植物化石种类数 目, 如同现代植物区系、种类数目一样, 相对来说, 都是贫乏的(中国科学院北京植物研究所和南京地 质古生物研究所, 1978; 吴向午, 1993, 2006)。然而, 从历史植物地理的角度看, 植物化石在植物区系地 理研究中占有重要位置。缺乏植物化石, 我们就不 能在时间尺度上对一个地区的植物区系和植被历 史有深刻地了解和认识; 对一个科属植物类群的进 化历史也会缺乏推断的基础, 或者推断的结论缺乏 说服力和可信度。因此, 要注重植物大化石和狍粉 数据的挖掘和采集。最近植物狍粉组合的研究, 对 新生代以来植物和环境对气候变化的响应, 提供了 有价值的证据, 例如见Sun \& Zhang (2008), Liu等 (2011), Miao等(2012)。

\section{3 互联网与数字标本馆利用}

目前的互联网数字标本馆已为植物区系、物种 多样性编目和分布资料等提供了基础信息, 并在植 物多样性保护等方面发挥了重要作用。建议有条件 的研究院所和大学加强和管理好互联网植物分类 和区系的信息, 它们将对植物区系地理研究发挥重 要作用, 并且随着这方面工作的加强, 植物区系、 物种多样性编目、分布资料等将会更方便、快捷地 利用, 植物区系地理研究将更具潜力和活力。

致谢：感谢两位审稿人提出了宝贵的修改意见。

\section{参考文献}

Avise JC (2000) Phylogeography: the History and Formation of Species. Harvard University Press, Cambridge, MA.

Bobrov EG (1965) On the origin of flora of the Old World deserts, as illustrated by the genus Nitraria L. Botanicheskii Zhurnal, 50, 1053-1067. (in Russian with English abstract)

Cao QM, Yin LK, Chen YF, Yang ML, Yang GQ (2015) Analysis on characteristics of flora in south slope of Altai Mountain. Acta Botanica Boreali-Occidentalia Sinica, 35, 1460-1469. (in Chinese with English abstract) [曹秋梅, 尹 林克, 陈艳锋, 杨美琳, 杨更强 (2015) 阿尔泰山南坡种
子植物区系特点分析. 西北植物学报, 35, 1460-1469.]

Chen P, Pan XL (2001) The floristic characteristics in the area of the Hexi Corridor. Bulletin of Botanical Research, 21, 24-30. (in Chinese with English abstract) [陈鹏, 潘晓玲 (2001) 河西走廊地区植物的区系特征. 植物研究, 21, 24-30.]

Chen WL, Yang CY (2000) A floristic study on the seed plant in Mts. Altay of China. Acta Botanica Yunnanica, 22, 371-378. (in Chinese with English abstract) [陈文俐, 杨昌 友 (2000) 中国阿尔泰山种子植物区系研究. 云南植物 研究, 22, 371-378.]

Cui DF, Liao WB, Zhang HD (2000) Analysis of the floristic geographical elements of families on the Xinjiang's spermatophytic flora. Arid Land Geography, 23, 326-330. (in Chinese with English abstract) [ 崔大方, 廖文波, 张宏达 (2000) 新疆种子植物科的区系地理成分分析. 干旱区地 理, 23, 326-330.]

Cui DF, Liao WB, Zhang HD (2001) Studies on the floristic geography of the woody flora from Xinjiang in China. Forest Research, 14, 553-559. (in Chinese with English abstract) [崔大方, 廖文波, 张宏达 (2001) 新疆木本植物区 系形成的探讨. 林业科学研究, 14, 553-559.]

Dang RL, Pan XL (2001) The Chinese endemic plant analysis in West-North Desert of China. Bulletin of Botanical Research, 21, 519-526. (in Chinese with English abstract) [党 荣理, 潘晓玲 (2001) 西北干旱荒漠区植物区系的特有 现象分析. 植物研究, 21, 519-526.]

Drummond AJ, Rambaut A (2007) BEAST: Bayesian evolutionary analysis by sampling trees. BMC Evolutionary Biology, 7, 214.

Eiserhardt WL, Svenning JC, Baker WJ, Couvreur TLP, Henrik B (2013) Dispersal and niche evolution jointly shape the geographic turnover of phylogenetic clades across continents. Scientific Reports, 3, 1164.

Feng Y, Pan BR (2004) Study on floristic and ecology of species endemic to Xinjiang. Acta Botanica Yunnanica, 26, 183-188. (in Chinese with English abstract) [冯纱, 潘伯荣 (2004) 新疆特有种植物区系及生态学研究. 云南植物研 究, 26, 183-188.]

Fu DZ, Zuo JB (1995) Quantitative study on seed plant flora of China. III. Flora index. Journal of Tropical and Subtropical Botany, 3(4), 23-29. (in Chinese with English abstract) [傅 德志, 左家哺 (1995) 中国种子植物区系定量化研究. III. 区系指数 (Flora Index). 热带亚热带植物学报, 3(4), 23-29.]

Gao LM (2015) Applications of DNA barcoding in biodiversity inventory and assessment. Biodiversity Science, 23, 286-287. (in Chinese) [高连明 (2015) DNA条形码在生物 多样性编目与评价中的应用. 生物多样性, 23, 286-287.]

Ge XJ (2015) Application of DNA barcoding in phylofloristics study. Biodiversity Science, 23, 295-296. (in Chinese) [葛 学军 (2015) DNA条形码在植物系统发育区系学研究中 的应用. 生物多样性, 23, 295-296.]

Ge XJ, Hwang CC, Liu ZH, Huang CC, Huang WH, Hung KH, 
Wang WK, Chiang TY (2011) Conservation genetics and phylogeography of endangered and endemic shrub Tetraena mongolica (Zygophyllaceae) in Inner Mongolia, China. BMC Genetics, 12, 1-12.

Ge XJ, Yu Y, Yuan YM, Huang HW, Yan C (2005) Genetic diversity and geographic differentiation in endangered $\mathrm{Am}$ mopiptanthus (Leguminosae) populations in desert regions of Northwest China as revealed by ISSR analysis. Annals of Botany, 95, 843-851.

Grubov VI (1999) Plants of Central Asia: Plant Collections from China and Mongolia. Science Publishers, Enfield.

Huang JH, Yang CY, Xiang QB (2014) Geographical composition analysis of species in Saur-tarbagatai Mountains in China. Acta Botanica Yunnanica, 26, 12-18. (in Chinese with English abstract) [黄俊华，杨昌友，向其柏 (2014) 中国萨吾尔-塔尔巴哈台山地种的地理成分分析. 云南植 物研究, 26, 12-18.]

Huang JH, Zhai SX, Yao YX, Dai YL, Song DH, Tahan W (2013) Seed plant flora of Tajikistan. Arid Land Geography, 36, 584-590. (in Chinese with English abstract) [黄俊华, 翟申修, 姚雨仙, 戴永丽, 宋丹华, 吾买尔夏提 - 塔汉 (2013) 塔吉克斯坦种子植物区系分析. 干旱区地理，36, 584-590.]

Iljin MM (1937) Summary of study of deserts flora of Middle Asia. Soviet Botanical Journal, 6, 95-109.

Jia DR, Abbott RJ, Liu TL, Mao KS, Bartish IV, Liu JQ (2012) Out of the Qinghai-Tibet Plateau: evidence for the origin and dispersal of Eurasian temperate plants from a phylogeographic study of Hippophaë rhamnoides (Elaeagnaceae). New Phytologist, 194, 1123-1133

Jia SW, Zhang ML, Raab-Straube EV, Thulin M (2016) Evolutionary history of Gymnocarpos (Caryophyllaceae) in the arid regions from North Africa to Central Asia. Biological Journal of Linnean Society, doi: 10.1111/bij.12834.

Jiang XL, Zhang ML, Zhang HH, Sanderosn SC (2014) Phylogeographic patterns of the Aconitum nemorum species group (Ranunculaceae) shaped by geological and climatic events in the Tianshan Mountains and their surroundings. Plant Systematics and Evolution, 300, 51-61.

Komarov VL (1908) Generis Caragana monographia. Acta Horti Petropolitani, 29, 179-388.

Komarov VL (1945) VL Komarov Opera Selecta, pp.159-342. Academic Science URSS, Moscow.

Komarov VL, Shishkin BK (eds.) (1934-1964) Flora Uniionis Rerumpublicarum Sovieticarum Socialisticarum, Vols 1-30. Nauka, Moskow/Leningrad. [Komarov VL, Shishkin BK (eds.) (1963-2002). Flora of USSR, Vols 1-30. Isreael Program for Scientific Translations, Jersalem; Amerind/Plymouth, England, Enfield, New Delhi; Science Press, NH.]

Kress WJ, Erickson DL, Jones FA, Swenson NG, Perez R, Sanjur O, Bermingham E (2009) Plant DNA barcodes and a community phylogeny of a tropical forest dynamics plot in Panama. Proceedings of the National Academy of Sciences, USA, 106, 18621-18626.

Li DZ, Gao LM, Li HT, Wang H, Ge XJ, Liu JQ, Chen ZD, Zhou SL, Chen SL, Yang JB, Fu CX, Zeng CX, Yan HF,
Zhu YJ, Sun YS, Chen SY, Zhao L, Wang K, Yang T, Duan GW (2011) Comparative analysis of a large dataset indicates that internal transcribed spacer (ITS) should be incorporated into the core barcode for seed plants. Proceedings of the $\mathrm{Na}$ tional Academy of Sciences, USA, 108, 19641-19646.

Li XY, Ma M, Yan P (1998) The index of the Pamirs seed plants in China. Journal of Shihezi University (Natural Science), 26, 266-280. (in Chinese with English abstract) [李学 禹，马沝，阎平 (1998) 中国帕米尔高原种子植物名录. 石河子大学学报(自然科学版), 26, 266-280.]

Li XH, Zhu XX, Niu Y, Sun H (2014) Phylogenetic clustering and overdispersion for alpine plants along elevational gradient in the Hengduan Mountains region. Journal of Systematics and Evolution, 52, 280-288.

Li ZH, Chen J, Zhao GF, Guo YP, Kou YX, Ma YZ, Wang G, Ma XF (2012) Response of a desert shrub to past geological and climatic change: a phylogeographic study of Reaumuria soongarica (Tamaricaceae) in western China. Journal of Systematics and Evolution, 50, 351-361.

Liu SE (1985) Collected Works of Liu Shene, pp. 270-274. Science Press, Beijing. (in Chinese) [刘慎谔 (1985) 刘慎 谔文集, 270-274页. 科学出版社, 北京.]

Liu YF, Wang Y, Huang HW (2009) Species-level phylogeographical history of Myricaria plants in the mountain ranges of western China and the origin of M. laxiflora in the Three Gorges mountain region. Molecular Ecology, 18, 2700-2712.

Liu YS, Utescher T, Zhou Z, Sun B (2011) The evolution of Miocene climates in north China: preliminary results of quantitative reconstructions from plant fossil records. Palaeogeography, Palaeoclimatology, Palaeoecology, 304, 308-317.

Liu YX (1982) Observations on the formation of Chinese desert floras. Acta Phytotaxonomica Sinica, 20, 131-141. (in Chinese with English abstract) [刘媖心 (1982) 我国荒漠 植物区系形成的探讨. 植物分类学报, 20, 131-141.]

Liu YX (1995) A study on origin and formation of the Chinese desert floras. Acta Phytotaxonomica Sinica, 33, 131-143. (in Chinese with English abstract) [刘媖心 (1995) 试论我 国沙漠地区植物区系的发生与形成. 植物分类学报，33, 131-143.]

Lu AM (1999) Geography of the Families and Genera of Chinese Seed Plants. Science Press, Beijing. (in Chinese) [路安 民 (1999) 种子植物科属地理. 科学出版社, 北京.]

Lu MM, Ci XQ, Yang GP, Li J (2013) DNA barcoding of subtropical forest trees: a study from Ailao Mountains Nature Reserve, Yunnan, China. Plant Diversity and Resources, 35, 733-741. (in Chinese with English abstract) [卢孟孟, 慈秀 芹, 杨国平, 李捷 (2013) 亚热带森林乔木树种DNA条形 码研究: 以哀牢山自然保护区为例. 植物分类与资源学 报, 35, 733-741.]

Lu MM, Huang XC, Ci XQ, Yang GP, Li J (2014) Phylogenetic community structure of subtropical forests along elevational gradients in Ailao Mountains of Southwest China. Biodiversity Science, 22, 438-448. (in Chinese with English 
abstract) [卢孟孟，黄小翠，慈秀芹，杨国平，李捷 (2014) 沿海拔梯度变化的哀牢山亚热带森林群落系统发育结构. 生物多样性, 22, 438-448.]

Ma JS (2011) The Outline of Taxonomic Literature of Eastern Asian Higher Plants. Higher Education Press, Beijing. (in Chinese) [马金双 (2011) 东亚高等植物分类学文献概览. 高等教育出版社, 北京.]

Ma SM, Zhang ML, Sanderson SC (2012) Phylogeography of the rare Gymnocarpos przewalskii (Caryophyllaceae): indications of multiple glacial refugia in north-western China. Australian Journal of Botany, 60, 20-31.

Meng HH, Gao XY, Huang JF, Zhang ML (2015) Plant phylogeography in arid Northwest China: retrospectives and perspectives. Journal of Systematics and Evolution, 53, 33-46.

Meng HH, Zhang ML (2013) Diversification of plant species in arid Northwest China: species-level phylogeographical history of Lagochilus Bunge ex Bentham (Lamiaceae). Molecular Phylogenetics and Evolution, 68, 398-409.

Mi XC, Pei NC, Ma KP (2014) A review on the progress of community phylogenetics. In: Annual Review of New Biology (ed. Muming Poo), pp. 266-289. Science Press, Beijing. (in Chinese) [米湘成, 裴男才, 马克平 (2014) 群落 系统发育学研究进展. 见: 新生物学年鉴2013 (蒲慕明主 编), 266-289页. 科学出版社, 北京.]

Miao YF, Herrmann M, Wu FL, Yan XL, Yang SL (2012) What controlled Mid-Late Miocene long-term aridification in Central Asia? Global cooling or Tibetan Plateau uplift: a review. Earth-Science Reviews, 112, 155-172.

Miao YF, Meng QQ, Fang XM, Yan XL, Wu FL, Song CH (2011) Origin and development of Artemisia (Asteraceae) in Asia and its implications for the uplift history of the Tibetan Plateau: a review. Quaternary International, 236, 3-12.

Nylander JAA, Olsson U, Alström P, Sanmartín I (2008) Accounting for phylogenetic uncertainty in biogeography: a Bayesian approach to dispersal-vicariance analysis of the thrushes (Aves: Turdus). Systematic Biology, 57, 257-268.

Pan XL (1994) The study on Tarim Basin flora. Journal of Xinjiang University (Natural Science Edition), 11(4), 77-83. (in Chinese with English abstract) [潘晓玲 (1994) 塔里木盆 地植物区系的研究. 新疆大学学报 (自然科学版), 11(4), 77-83.]

Pan XL, Dang RL, Wu GH (2001) Flora Geography and Resources Utilization in Arid Northwest Desert. Science Press, Beijing. (in Chinese) [潘晓玲, 党荣理, 伍光和 (2001) 西北 干旱荒漠区植物区系地理与资源利用. 科学出版社, 北京.]

Pan XL, Shen GM, Chen P (1999) A preliminary research on taxonomy and systematics of genus Nitraria. Acta Botanica Yunnanica, 21, 287-295. (in Chinese with English abstract) [潘晓玲, 沈观冕, 陈鹏 (1999) 白刺属植物的分类学及 系统学研究. 云南植物研究, 21, 287-295.]

Pan XL, Zhang HD (1995) An analysis on the flora and the research on forming of that in Tsaidam Basin. Journal of Xinjiang University (Natural Science Edition), 12(1), 81-86. (in Chinese with English abstract) [潘晓玲, 张宏达 (1995)
柴达木盆地植物区系分析及其形成的探讨. 新疆大学学 报(自然科学版), 12(1), 81-86.]

Pan XL, Zhang HD (1996) Diagnosis on the characters of the vegetation and flora in Kanas, Altai. Ecological Science, 15(2), 32-37. (in Chinese with English abstract) [潘晓玲, 张宏达 (1996) 哈纳斯自然保护区植被特点及植物区系 形成的探讨. 生态科学, 15(2), 32-37.]

Pan XL, Zuo JB (1997) Quantitative study on seed flora resemblance in northwestern China. Acta Botanica Boreali-Occidentalia Sinica, 17, 94-102. (in Chinese with English abstract) [潘晓玲, 左家哺 (1997) 中国西北地区种子 植物区系相似性的定量研究. 西北植物学报, 17, 94-102.]

Pan XY, Wei XP, Yu QS, Chen JK, Wang GX (2003) Polyploidy: classification, evolution and applied perspective of the genus Nitraria L. Chinese Bulletin of Botany, 20, 632-638. [潘晓云, 魏小平, 尉秋实, 陈家宽, 王根轩 (2003) 多倍化一白刺属的系统分类、进化特征及应用前 景. 植物学通报, 20, 632-638.]

Qian H, Jiang L (2014) Phylogenetic community ecology: integrating community ecology and evolutionary biology. Journal of Plant Ecology, 7, 97-100.

Qiu YX, Fu CX, Comes HP (2011) Plant molecular phylogeography in China and adjacent regions: tracing the genetic imprints of quaternary climate and environmental change in the world's most diverse temperate flora. Molecular Phylogenetics and Evolution, 59, 225-244.

Ree RH, Smith SA (2008) Maximum likelihood inference of geographic range evolution by dispersal, local extinction, and cladogenesis. Systematic Biology, 57, 4-14.

Ren J, Tao L (2003) Quantitative analysis of similarity of Chinese desert plant floras. Journal of Desert Research, 23, 289-294. (in Chinese with English abstract) [任珺, 陶玲 (2003) 中国沙漠植物区系相似性的数值分析. 中国沙漠, 23, 289-294.]

Renner SS (2005) Relaxed molecular clocks for dating historical plant dispersal events. Trends in Plant Science, 10, 550-558.

Ricklefs RE (2007) Estimating diversification rates from phylogenetic information. Trends in Ecology \& Evolution, 22, 601-610.

Sanderson MJ (2002) Estimating absolute rates of molecular evolution and divergence times: a penalized likelihood approach. Molecular Biology and Evolution, 19, 101-109.

Shi XJ, Zhang ML (2015) Phylogeographical structure inferred from cpDNA sequence variation of Zygophyllum xanthoxylon across North-west China. Journal of Plant Research, 128, 269-282.

Su ZH, Zhang ML, Sanderson SC (2011) Chloroplast phylogeography of Helianthemum songaricum (Cistaceae) from northwestern China: implications for preservation of genetic diversity. Conservation Genetics, 12, 1525-1537.

Su ZH, Zhang ML (2013) Evolutionary response to Quaternary climate aridification and oscillations in northwestern China revealed by chloroplast phylogeography of Nitraria sphaerocarpa (Nitrariaceae). Biological Journal of the Linnean Society, 109, 757-770. 
Sun JM, Zhang ZQ (2008) Palynological evidence for the Mid-Miocene climatic optimum recorded in Cenozoic sediments of the Tian Shan Range, northwestern China. Global and Planetary Change, 64, 53-68.

Takhtajan A (1986) Floristic Regions of the World. University of California Press, Berkeley.

Tang YC (2000) On the affinities and the role of the Chinese flora. Acta Botanica Yunnanica, 22, 1-26. (in Chinese with English abstract) [汤彦承 (2000) 中国植物区系与其它地 区区系的联系及其在世界区系中的地位和作用. 云南植 物研究, 22, 1-26.]

Temirbayeva K, Zhang ML (2015) Molecular phylogenetic and biogeographical analysis of Nitraria based on nuclear and chloroplast DNA sequences. Plant Systematics and Evolution, 301, 1897-1906.

The Editorial Committee of Chinese Physical Geography of the Chinese Academy of Sciences (1985) Physical Geography of China: General Introduction. Science Press, Beijing. (in Chinese) [中国科学院《中国自然地理》编辑委员会 (1985) 中国自然地理: 总论. 科学出版社, 北京.]

Vassilchenko IT (1982) On the origin of the flora of Middle Asia. Botanicheskii Zhurnal, 67, 722-728.

Wang HS (1979) The basic features of Chinese flora. Acta Geographica Sinica, 34, 224-237. (in Chinese with English abstract) [王荷生 (1979) 中国植物区系的基本特征. 地 理学报, 34, 224-237.]

Wang HS (1992) Floristic Geography. Science Press, Beijing. (in Chinese) [王荷生 (1992) 植物区系地理. 科学出版社, 北京.]

Webb CO, Ackerly DD, McPeek MA, Donoghue MJ (2002) Phylogenies and community ecology. Annual Review of Ecology and Systematics, 33, 475-505.

Wiens JJ, Parra-Olea G, Garcia-Paris MM, Wake DB (2007) Phylogenetic history underlies elevational biodiversity patterns in tropical salamanders. Proceedings of the Royal Society B: Biological Sciences, 274, 919-928.

Wu CY (1979) The regionalization of Chinese flora. Acta Botanica Yunnanica, 1, 1-22. (in Chinese with English abstract) [吴征镒 (1979) 论中国植物区系的分区问题. 云 南植物研究, 1, 1-22.]

Wu CY, Wang HS (1983) Physical Geography of China: Phytogeography (I). Science Press, Beijing. (in Chinese) [吴征 镒, 王荷生 (1983) 中国自然地理: 植物地理(上册). 科 学出版社, 北京.]

Wu CY, Sun H, Zhou ZK, Li DZ, Peng H (2011) Phytogeography of Chinese Seed Plants. Science Press, Beijing. (in Chinese) [ 吴征镒, 孙航, 周浙昆, 李德铢, 彭华 (2011) 中国种子植物区系地理. 科学出版社, 北京.]

Wu CY, Wu SG (1998) A proposal for new floristic kingdom (realm) - the E. Asiatic kingdom, its delimitation and characteristics. In: Floristic Characteristics and Diversity of East Asian Plants (eds Zhang AL, Wu SG). China Higher Education Press, Beijing and Springer-Verlag, Hongkong.

Wu XW (1993) Index of generic names founded on Mesozoic-Cenozoic specimens from China in 1865-1990. Acta
Palaeontologica Sinica, 32, 495-524. (in Chinese with English abstract) [吴向午 (1993) 中国中、新生代大植物化石 新属索引(1865-1990). 古生物学报, 32, 495-524.]

Wu XW (2006) Record of Mesozoic-Cenozoic megafossil plant generic names founded on Chinese specimens (1991-2000). Acta Palaeontologica Sinica, 45, 114-140. (in Chinese and English) [吴向午 (2006) 中国中、新生代大植物化石新属 记录(1991-2000). 古生物学报, 45, 114-140.]

Wulff EV (translated by Zhong CX, Lu DA, Shen ZA, Hong BG, Wu YS, Yao ZH, Zhou HB) (1964) Historical Plant Geography. Science Press, Beijing. (in Chinese) [仲崇信, 陆定安, 沈祖安, 洪必恭, 吴玉树, 姚中和, 周鸿涁 (译) (1964) 历史植物地理学. 科学出版社, 北京.]

Xie KQ, Zhang ML (2013) The effect of Quaternary climatic oscillations on Ribes meyeri (Saxifragaceae) in northwestern China. Biochemical Systematics and Ecology, 50, 39-47.

Xinjiang Integrated Exploration Team, Institute of Botany, Chinese Academy of Sciences (1978) Xinjiang Vegetation and Its Application. Science Press, Beijing. (in Chinese) [中 国科学院新疆综合考察队, 中国科学院植物研究所 (1978) 新疆植被及其利用. 科学出版社, 北京.]

Xinjiang Integrated Exploration Team, Chinese Academy of Sciences (1959) Reports of Xinjiang Integrated Exploration, pp. 128-186. Science Press, Beijing. (in Chinese) [中国科 学院新疆综合考察队 (1959) 新疆综合考察报告汇编, 128-186页. 科学出版社, 北京.]

Xu YJ, Chen YN, Li WH, Fu AH, Ma XD, Gui DW, Chen YP (2010) Distribution pattern and environmental interpretation of plant species diversity in the mountainous region of Ili River Valley, Xinjiang, China. Chinese Journal of Plant Ecology, 34, 1142-1154. (in Chinese with English abstract) [徐远杰, 陈亚宁, 李卫红, 付爱红, 马晓东, 桂东伟, 陈 亚鹏 (2010) 伊犁河谷山地植物群落物种多样性分布格 局及环境解释. 植物生态学报, 34, 1142-1154.]

Xu Z, Zhang ML (2015) Phylogeography of the arid shrub Atraphaxis frutescens (Polygonaceae) in northwestern China, evidence from cpDNA sequences. Journal of Heredity, 106, 184-195.

Yan L, Wan T, Liu J (1999) Observation on the pollen morphology of endemic plants in Alashan Desert. Journal of Arid Land Resources and Environment, 13(2), 33-40. (in Chinese with English abstract) [燕玲, 宛涛, 刘军 (1999) 阿拉善荒漠区特有植物与特征植物花粉形态的研究. 干 旱区资源与环境, 13(2), 33-40.]

Yang QZ (2006) A discussion about new record in W. Sichuan and discontinuous distribution ways of Australia for genus Nitraria L. Journal of Mountain Science, 24, 137-143.

Yang SP, Xu HY, Yan P (2007) Floristic elements of seed plants in the Pamirs Region of China. Chinese Bulletin of Botany, 24, 597-602. (in Chinese with English abstract) [杨 淑萍，徐海燕，阎平 (2007) 中国帕米尔高原种子植物区 系的特征. 植物学通报, 24, 597-602.]

Yong SP, Zhu ZY (1990) A fundamental characteristics of gobi desert flora in the centre Asia. Acta Scientiarum Naturalium 
Universitatis Intramongolicae, 21, 241-247. (in Chinese) [雍世鹏, 朱宗元 (1990) 论戈壁荒漠植物区系的基本特 性. 内蒙古大学学报(自然科学版), 21, 241-247.]

Yong SP, Zhu ZY (1992) A certain fundamental characteristics of gobi desert vegetation in the centre Asia. Acta Scientiarum Naturalium Universitatis Intramongolicae, 23, 235-244. (in Chinese with English abstract) [雍世鹏, 朱宗元 (1992) 论戈壁荒漠生态区植被的若干基本特征. 内蒙古大学学 报 (自然科学版), 23, 235-244.]

Yu Y, Harris AJ, Blair C, He X (2015) RASP (reconstruct ancestral state in phylogenies): a tool for historical biogeography. Molecular Phylogenetics and Evolution, 87, 46-49.

Zhang DY, Pan BR, Yin LK (2003) The phytogeographical studies of Tamarix (Tamaricaceae). Acta Botanica Yunnanica, 25, 415-427. (in Chinese with English abstract) [张 道远, 潘伯荣, 尹林克 (2003) 柽柳科柽柳属的植物地理 研究. 云南植物研究, 25, 415-427.]

Zhang HX, Zhang ML (2012) Genetic structure of the Delphinium naviculare species group tracks Pleistocene climatic oscillations in the Tianshan Mountains, arid Central Asia. Palaeogeography, Palaeoclimatology, Palaeoecology, 353-355, 93-103.

Zhang ML (1998) A preliminary analytic biogeography in Caragana (Fabaceae). Acta Botanica Yunnanica, 20, 1-11. (in Chinese with English abstract) [张明理 (1998) 锦鸡儿 属分析生物地理学的研究. 云南植物研究, 20, 1-11.]

Zhang ML, Fritsch PW (2010) Evolutionary response of Caragana (Fabaceae) to Qinghai-Tibetan Plateau uplift and Asian interior aridification. Plant Systematics and Evolution, 288, 191-199.

Zhang ML, Fritsch PW, Cruz BC (2009) Phylogeny of Caragana (Fabaceae) based on DNA sequence data from rbcL, trnS-trnG, and ITS. Molecular Phylogenetics and Evolution, 50, 547-559.

Zhang ML, Hao XL, Sanderson SC, Byalt VV, Sukhoruhov AP, Zhang X (2014a) Spatiotemporal evolution of Reaumuria (Tamaricaceae) in Central Asia: insights from molecular biogeography. Phytotaxa, 167, 89-103.

Zhang ML, Sanderson SC, Sun YX, Byalt VV, Hao XL (2014b) Tertiary montane origin of the Central Asian flora, evidence inferred from cpDNA sequences of Atraphaxis (Polygonaceae). Journal of Integrative Plant Biology, 56, 1125-1135.

Zhang ML, Temirbayeva K, Sanderson SC, Chen X (2015a) Young dispersal of xerophil Nitraria lineages in intercontinental disjunctions of the Old World. Scientific Reports, 5, 13840 .

Zhang ML, Xue JJ, Zhang Q, Sanderson SC (2015b) Inferring ancestral distribution area and survival vegetation of Caragana (Fabaceae) in Neogene. Plant Systematics and Evolution, 301, 1831-1842.

Zhang YL (1998) Coefficient of similarity—an important parameter in floristic geography. Geographical Research, 17, 429-434. (in Chinese with English abstract) [张镱锂 (1998) 植物区系地理研究中的重要参数: 相似性系数. 地理研
究, 17, 429-434.]

Zhao YB, Cui DF, Li XY, Yan P, Ma M (2003) Analysis on spermatophytic constituent and resources characteristics on the Pamirs in China. Journal of Plant Resources and Environment, 12(3), 44-49. (in Chinese with English abstract) [赵业涁, 崔大方, 李学禹, 阎平, 马沝 (2003) 中国帕米 尔高原种子植物组成及其资源分析. 植物资源与环境学 报, 12(3), 44-49.]

Zhao YZ (1993) Taxonomic study of the genus Caragana from China. Acta Scientiarum Naturalium Universitatis Intramongolicae, 24, 631-653. (in Chinese with English abstract) [赵一之 (1993) 中国锦鸡儿属的分类学研究. 内蒙古大 学学报(自然科学版), 24, 631一653.]

Zhao YZ (1997) Endemic genera and their basic characteristics of the Mongolian Plateau plants. Acta Scientiarum Naturalium Universitatis Intramongolicae, 28, 547-552. (in Chinese with English abstract) [ 赵一之 (1997) 蒙古高原植物的特 有属及其基本特征. 内蒙古大学学报 (自然科学版), 28 , 547-552.]

Zhao YZ (2006) Vascular Plants of Ordos. Inner Mongolia University Press, Huohot. [赵一之 (2006) 鄂尔多斯高原 维管植物. 内蒙古大学出版社, 呼和浩特.]

Zhao YZ (2009) Classification and its floristic geography of Caragana Fabr. in the world. Inner Mongolia University Press, Huohot. [赵一之 (2009) 世界锦鸡儿属植物分类及 其区系地理. 内蒙古大学出版社, 呼和浩特.]

Zhao YZ (2014) Diagnostic Key of Vascular Plants in Inner Mongolia. Science Press, Beijing. [赵一之 (2014) 内蒙古 维管植物检索表. 科学出版社, 北京.]

Zhao YZ, Zhu ZY (2003) The endemic genera of desert region in Central Asia. Acta Botanica Yunnanica, 25, 113-121. (in Chinese with English abstract) [赵一之, 朱宗元 (2003) 亚 洲中部荒漠区的植物特有属.云南植物研究, 25 , 113-121.]

Institute of Botany, Nanjing Institute of Geology and Palaeontology, Academia Sinica (1978) Chinese Plant Fossils. Vol. 3. Science Press, Beijing. [中国科学院北京植物研究所, 南京地质古生物研究所 (1978) 中国新生代植物. 中国 植物化石(第三卷). 科学出版社, 北京.]

Zhu GL (1996) Origin, differentiation, and geographic distribution of the Chenopodiaceae. Acta Phytotaxonomica Sinica, 34, 486-504. (in Chinese with English abstract) [朱格麟 (1996) 藜科植物的起源、分化和地理分布. 植物分类学 报, 34, 486-504.]

Zhu ZY, Ma YQ, Liu ZL, Zhao YZ (1999) Endemic plants and floristic characteristics in Alashan-Ordos biodiversity center. Journal of Arid Land Resources and Environment, 13(2), 1-16. (in Chinese with English abstract) [朱宗元, 马毓泉, 刘钟龄, 赵一之 (1999) 阿拉善-鄂尔多斯生物多样性中 心的特有植物和植物区系的性质. 干旱区资源与环境, 13(2), 1-16.]

(责任编委: 王国宏 责任编辑: 间文杰) 